\title{
REVISED GEOLOGIC MAP AND STRUCTURAL MODEL OF THE STANIUKOVICH PENINSULA-HERENDEEN BAY AREA
}

\author{
by
}

Paul L. Decker ${ }^{1}$, Rocky R. Reifenstuhl², Robert J. Gillis², and Andrea Loveland²

\begin{abstract}
Recent geologic mapping provides valuable insights into the structural configuration and hydrocarbon potential south of Port Moller on the northwestern side of the Alaska Peninsula. The study area encompasses most of the onshore lands leased for oil and gas exploration during 2005 and 2006. The region has a polyphase Mesozoic and Cenozoic tectonic history, as reflected by multiple magmatic stages and numerous unconformities in the stratigraphic record. The northwestern part of the map area is a low-relief coastal plain traversed by the David River zone, the southern structural margin of the North Aleutian backarc basin. Both extensional and compressional structures occur in this zone, and faulting is believed to involve a significant right-lateral strike-slip component. Upland areas to the south are dominated by uplifted Mesozoic and Tertiary units. Important differences in structural style and complexity distinguish exposures west of Herendeen Bay (the Sapsuk domain) from rocks of the peninsula between Herendeen Bay and Port Moller (the Staniukovich domain). Although it was not mapped in detail for this study, the Sapsuk domain is dominated by a single, broad uplift cored by a major thrust or reverse fault but traversed by few second-order faults or folds. In contrast, the Staniukovich domain hosts a large, doubly-plunging, complexly faulted rhomboid-shaped uplift (the Staniukovich anticline) as well as narrower, fault-bounded folds to the south. This study finds no structural or stratigraphic evidence for major low-angle overthrusting in the map area, as has been interpreted by previous workers. Instead, kinematic observations indicate deformation occurred through a combination of folding and oblique-slip on at least two sets of steep, intersecting faults, which strike sub-parallel and transverse to the axis of the Staniukovich uplift, respectively. This complex network of longitudinal and transverse faults makes it unlikely that the Staniukovich anticline behaves as a single large hydrocarbon trap, but it may encompass numerous smaller, fault-bounded trapping configurations. Analog experiments on deformation at restraining oversteps in strike-slip regimes generate models that closely resemble the structural styles and patterns mapped in the study area. This supports a structural model for key stages of the area's tectonic history based on right-lateral transpression along left-stepping strands of the David River zone, with the rhomboidal uplift on the Staniukovich peninsula localized within the restraining overstep itself.
\end{abstract}

\section{INTRODUCTION}

The southwestern Alaska Peninsula offers broad areas of relatively well exposed Mesozoic and Tertiary rocks, particularly in the area of this study along the embayed shorelines of Port Moller, Herendeen Bay, and in much of the highlands of the peninsula between these inlets (fig. 1). Informally named in this report after Staniukovich Mountain, its highest point (elevation $\sim 775 \mathrm{~m}[\sim 2,550 \mathrm{ft}]$ ), the Staniukovich peninsula is dominated by a large, doubly-plunging anticlinal uplift with Jurassic Naknek Formation exposed in the core, and rocks as young as the Miocene Bear Lake Formation in scattered outcrops at its flanks. Large anticlines also occur west and southwest of Herendeen Bay. Beyond this basic description, previous geologic maps of the area present strikingly different map patterns corresponding to fundamentally different stratigraphic interpretations and structural implications (Atwood, 1911; Burk, 1965; Amoco, unpublished mapping, 1979, 1983; Wilson and others, 1995; Wilson and others, 1999).

The renewal of oil and gas leasing on the Alaska Peninsula in 2005 attracted independent bidding by two companies, both focused exclusively in the Staniukovich peninsula-Herendeen Bay area (fig. 1), presumably due to a combination of factors. Here, Mesozoic and Tertiary strata are relatively well exposed, revealing the potential for large anticlinal and fault-bounded structural traps in both successions. Shortly before the 2005 sale, analysis of the prolific natural gas seep at Port Moller hot spring near the axis of the anticline on the northeastern Staniukovich peninsula showed it to consist of nearly pure, thermogenic methane (Decker and others, 2005). The integration of outcrop studies with offshore seismic interpretations reveals that the area of industry attention is adjacent to an underexplored probable hydrocarbon source kitchen in the axis of the North Aleutian basin. The area contains an eastern segment of the so-called David River zone (Amoco, 1979), the complex boundary between the Tertiary-filled North Aleutian basin to

${ }^{1}$ Alaska Division of Oil \& Gas, 550 W. 7th Ave., Suite 800, Anchorage, Alaska 99501

${ }^{2}$ Alaska Division of Geological \& Geophysical Surveys, 3354 College Rd., Fairbanks, Alaska 99709-3707 


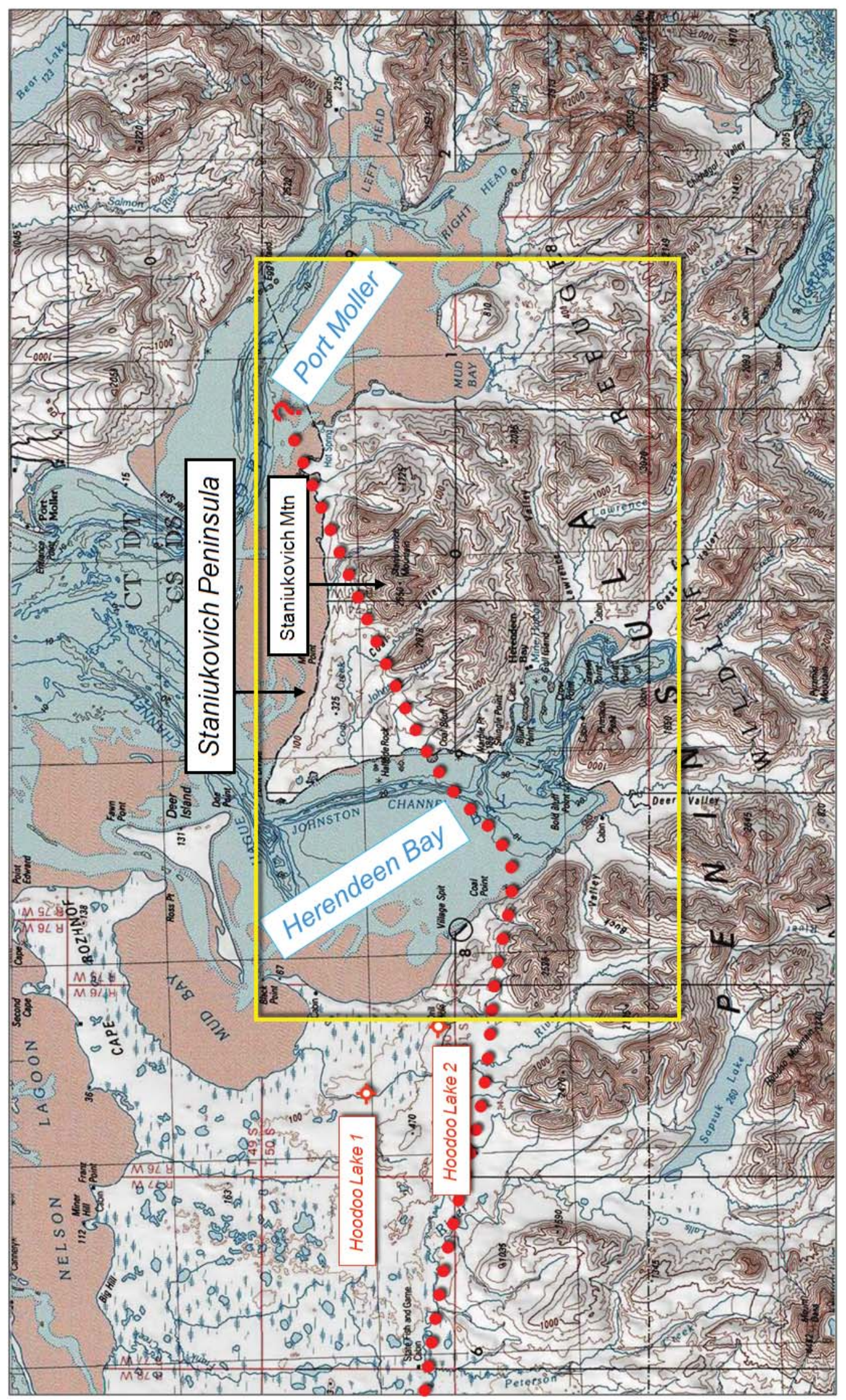

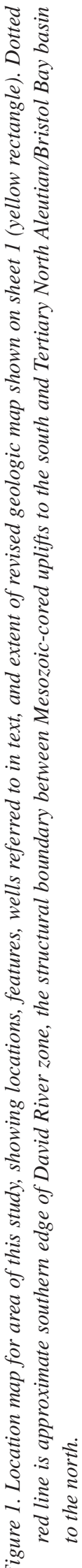


the north and the uplifted Mesozoic rocks to the south (fig. 1; Decker and others, 2005; Finzel and others, 2005; Worrall, 1991).

Given the convergence of geologic potential, industry interest, and widely varying existing interpretations, the State of Alaska required map-based geologic interpretations to evaluate oil and gas resource potential on State lands in this part of the Alaska Peninsula. This report describes geologic mapping and structural studies conducted during 2005 and 2006 to address that need.

\section{PREVIOUS GEOLOGIC MAPPING}

Reporting primarily on coal and other mineral resources of the Alaska Peninsula, Atwood (1911) made valuable structural and stratigraphic contributions and published a highly schematic regional geologic map.
He defined the Lower Cretaceous Staniukovich shale, which he named after the smooth, dull reddish slopes making up much of Staniukovich Mountain. His simplified regional cross section from Port Moller through Unga Island depicts the basic anticlinal structure of the Staniukovich peninsula.

Burk (1965) published a more complete 1:250,000scale map of the Alaska Peninsula southwest of Wide Bay. Ranging widely across the region by helicopter and boat, Burk and a geological assistant conducted three seasons of mapping and stratigraphic studies, and developed a comprehensive geologic history and generalized structural framework. He recognized the doubly-plunging Staniukovich Mountain anticline and adjacent narrower folds to the south, which he mapped as having minor complications due to longitudinal faults (fig. 2). Burk (1965, p. 128) described the Staniukovich

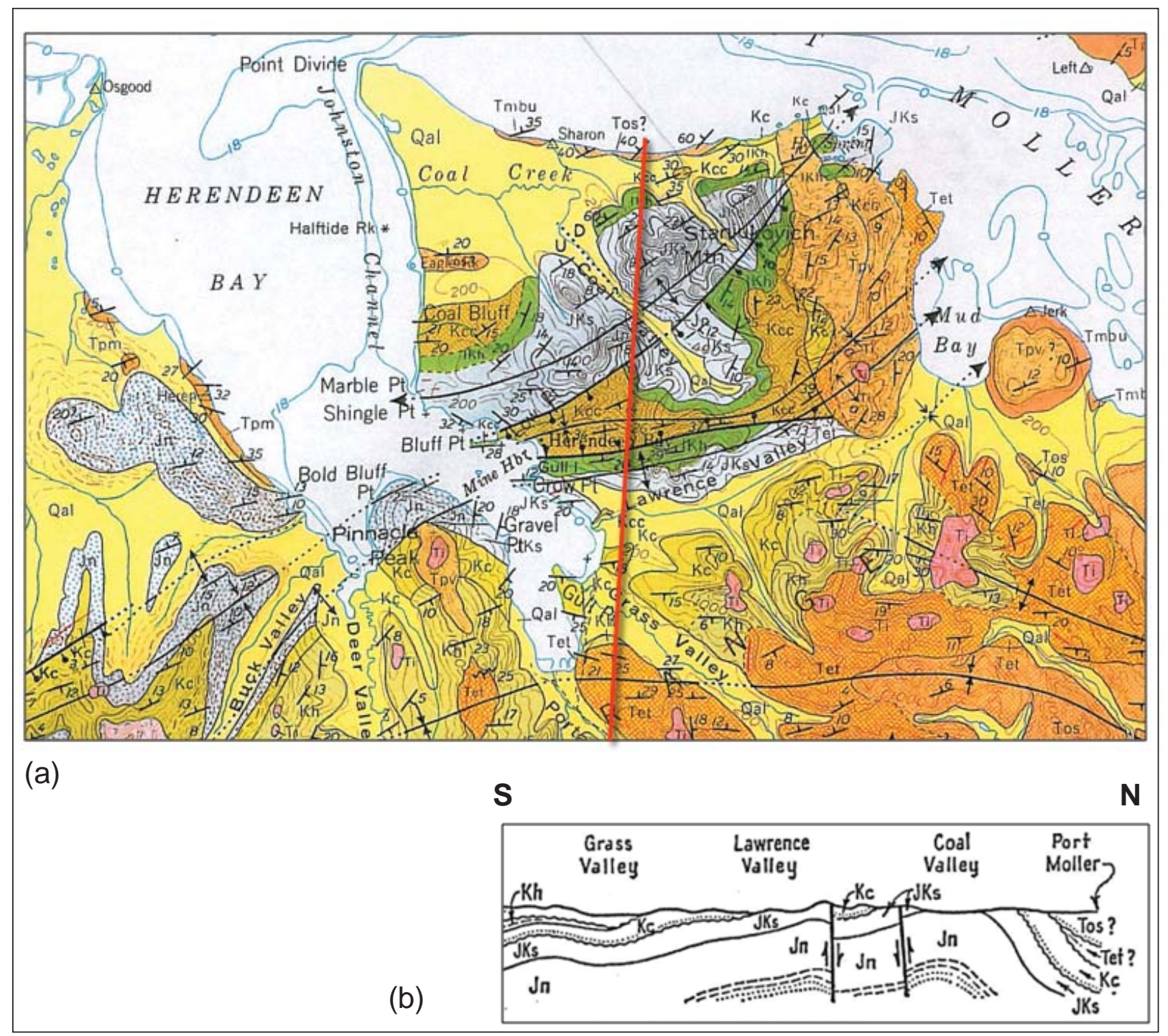

Figure 2. Excerpts from the regional geologic map and figures of Burk (1965). Geologic map (a) and generalized cross section (b) of the present study area in the Staniukovich peninsula-Herendeen Bay area. Compare to figures 3, 4, and sheet 1. 
Mountain anticline and the large uplift west of Herendeen Bay as parts of a continuous, northeast-plunging anticlinal uplift that extends east of Port Moller. He also expanded Atwood's (1911) definition of the Staniukovich Formation to encompass older and coarser-grained rocks, including Upper Jurassic feldspathic sandstones, arkoses, and conglomerates previously assigned to the Naknek Formation (Burk, 1965, p. 39-45). In keeping with his revised definition, Burk mapped no Naknek Formation on the Staniukovich peninsula.
Previously confidential geologic maps and reports generated by Amoco Production Company over the course of several field seasons were publicly released during 2004 and are available for inspection at the Alaska Division of Geological \& Geophysical Surveys Geologic Materials Center in Eagle River, Alaska. Particularly useful is an annotated 1:192,000 (1 inch = 16,000 feet) scale regional geologic map of the entire Alaska Peninsula (fig. 3a; Amoco, 1979) that incorporated interpretations and analytical results from numerous published and

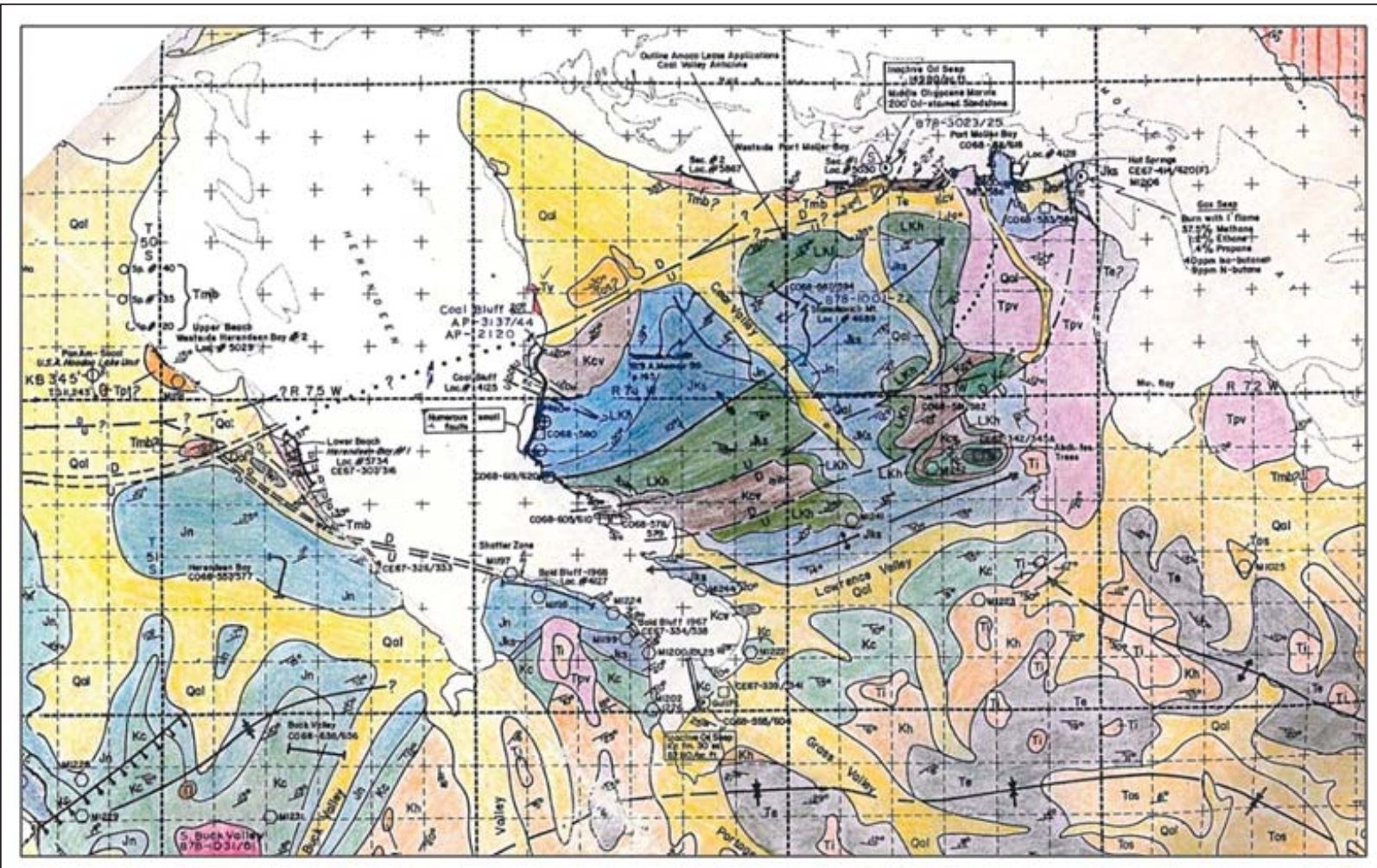

(a)

(b)

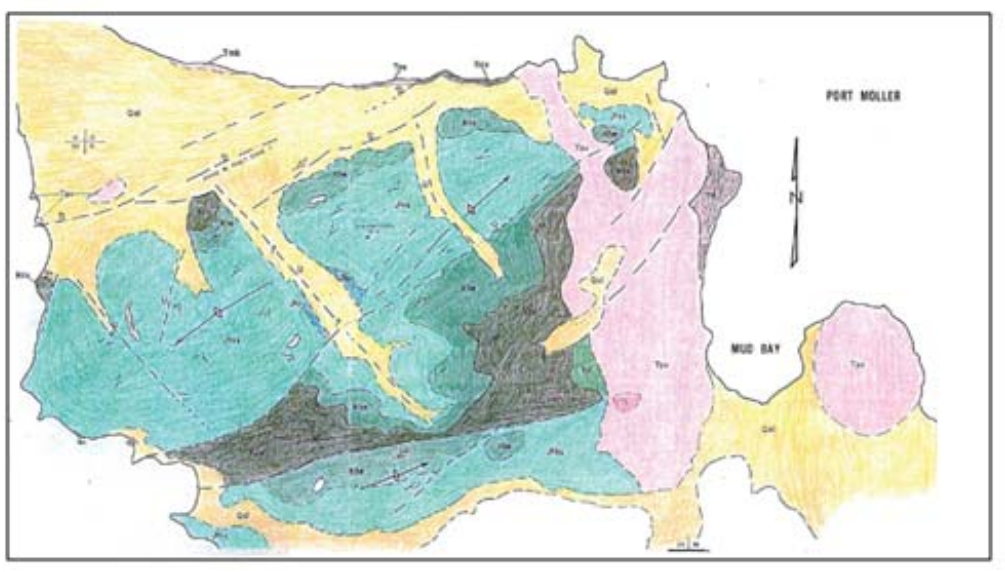

Figure 3. Unpublished geologic maps of the study area in the Staniukovich peninsula-Herendeen Bay area from Amoco Production Company field reports. Figure (a) is excerpted from 1:192,000-scale regional map (Amoco, 1979); (b) is reduced to approximately the same scale from 1:63,360-scale map restricted to the Staniukovich peninsula (Amoco, 1983). Neither included a cross section through the present study area. Compare to figs. 2, 4, and sheet 1. 
unpublished sources. In the present study area, Amoco (1979) made substantial revisions to the map pattern of Burk (1965), and added important outcrop- and geophysically-based structural interpretations, including faults in areas obscured by surficial cover. Subsequent remapping of parts of the Staniukovich peninsula at 1:63,360 ( 1 inch $=1$ mile) scale by Amoco geologists recognized three significant faults nearly perpendicular to and locally offsetting the axis of the Staniukovich Mountain anticline (fig. 3b; Amoco, 1983). This map differed markedly from both Burk's (1965) and Amoco's (1979) previous maps in terms of the distribution of Lower Cretaceous and Upper Jurassic rocks units.

U.S. Geological Survey publications (Wilson and others, 1995; 1999) represent the most comprehensive existing geologic mapping in the study area. The 1:250,000-scale map of Wilson and others (1995) emphasized the structural complexity of the Staniukovich peninsula, depicting numerous relatively straight (high-angle) faults oriented sub-parallel and transverse to the fold axes (fig. 4a). Additionally, USGS geologists inferred the existence of a low-angle thrust fault believed to have emplaced a complexly faulted upper plate consisting of blocks of Jurassic through Paleogene units above a relatively undeformed lower plate that includes Tertiary strata as young as Miocene Bear Lake Formation (fig. 4b; Wilson and others, 1995; Detterman and others, 1996, p. 31).

With important exceptions, the mapping and structural fabric observations of the present study (sheet 1) mostly corroborate the distribution of rock units and high-angle faults mapped by USGS workers (Wilson and others, 1995; 1999). However, our findings do not support the low-angle thrusting interpretation offered by Wilson and others (1995) and Detterman and others (1996). Although the present study significantly revises all previous mapping, we rely largely on the USGS mapping for coverage where we were unable to make our own observations, particularly in the southeastern and southwestern corners of the map (sheet 1 ). In other areas west of Herendeen Bay, we have modified USGS mapping based in part on remote sensing and field observations made by Sralla (2007) on behalf of Hewitt Mineral Corporation following successful bidding in the 2005 lease sale.

\section{REVISED GEOLOGIC MAPPING OF THIS STUDY FIELD METHODS}

The geologic mapping of this study was performed in conjunction with other stratigraphic and structural field objectives (Gillis and others, 2007; Decker and others, 2005; Finzel and others, 2005). Three to four geologists conducted helicopter-supported mapping traverses, beginning with long coastal exposures, and working into more vegetated upland areas as weather permitted. Mapping of formation and fault contacts was complemented by collection of structural orientation and kinematic data (primarily fault planes, slickenlines, and slip sense indicators) where exposures allowed. These data have been plotted in lower hemisphere stereographic projections in figure 6 . The 1:50,000-scale preliminary revised geologic map and cross sections (sheet 1 ) includes these structural fabric stereograms as inset figures. Due to time and logistical constraints, mapping efforts were focused more on the Staniukovich peninsula than on the structurally-simpler areas to the west and south.

\section{MAPPED ROCK UNITS}

Definitive formation calls are often difficult to make in Alaska Peninsula strata, both in the field and from laboratory analyses. The Jurassic through Pliocene sedimentary record is thought to contain as many as ten unconformities (Detterman and others, 1996), and sediments from older units are recycled into younger units, probably more than once in some cases. The framework composition of some sedimentary units varies significantly throughout the region depending on unconformity subcrop and on local variations in the sediment source area. The provenance area consists of arkosic and volcaniclastic sedimentary units and superimposed intermediate to felsic magmatic arcs of Triassic through Quaternary age (for example, Wilson, 1985; Detterman and others, 1996; Wilson and others, 1999). Furthermore, many sedimentary units share a wide range of textures and nonmarine to shallow marine facies associations. Additionally, the megafauna and megaflora assemblages used to characterize some units can be difficult to distinguish without considerable paleontologic expertise. Micropaleontology studies are useful, but they obviously require laboratory preparation and analyses. Volcanic map units of similar composition may be easily mistaken for each other in the field; previous maps are in conflict regarding the age assigned to some lavas. In the absence of diagnostic cross-cutting relationships, age designations for the basaltic and andesitic units are determined better by radiometric methods than by subjective field criteria such as degree of weathering.

These caveats notwithstanding, the preliminary mapping of this study (sheet 1 ) recognizes ten sedimentary bedrock units and four primary igneous units of Upper Jurassic through Pliocene age, and adopts the four Quaternary surficial map units of Wilson and others (1995). Other than as noted in the text, map unit descriptions and outcrop photographs are found on sheet 2. These unit descriptions are adapted from Wilson and others (1995), consisting of excerpted text that has been modified as necessary to reflect the scope and interpretations of our mapping. 


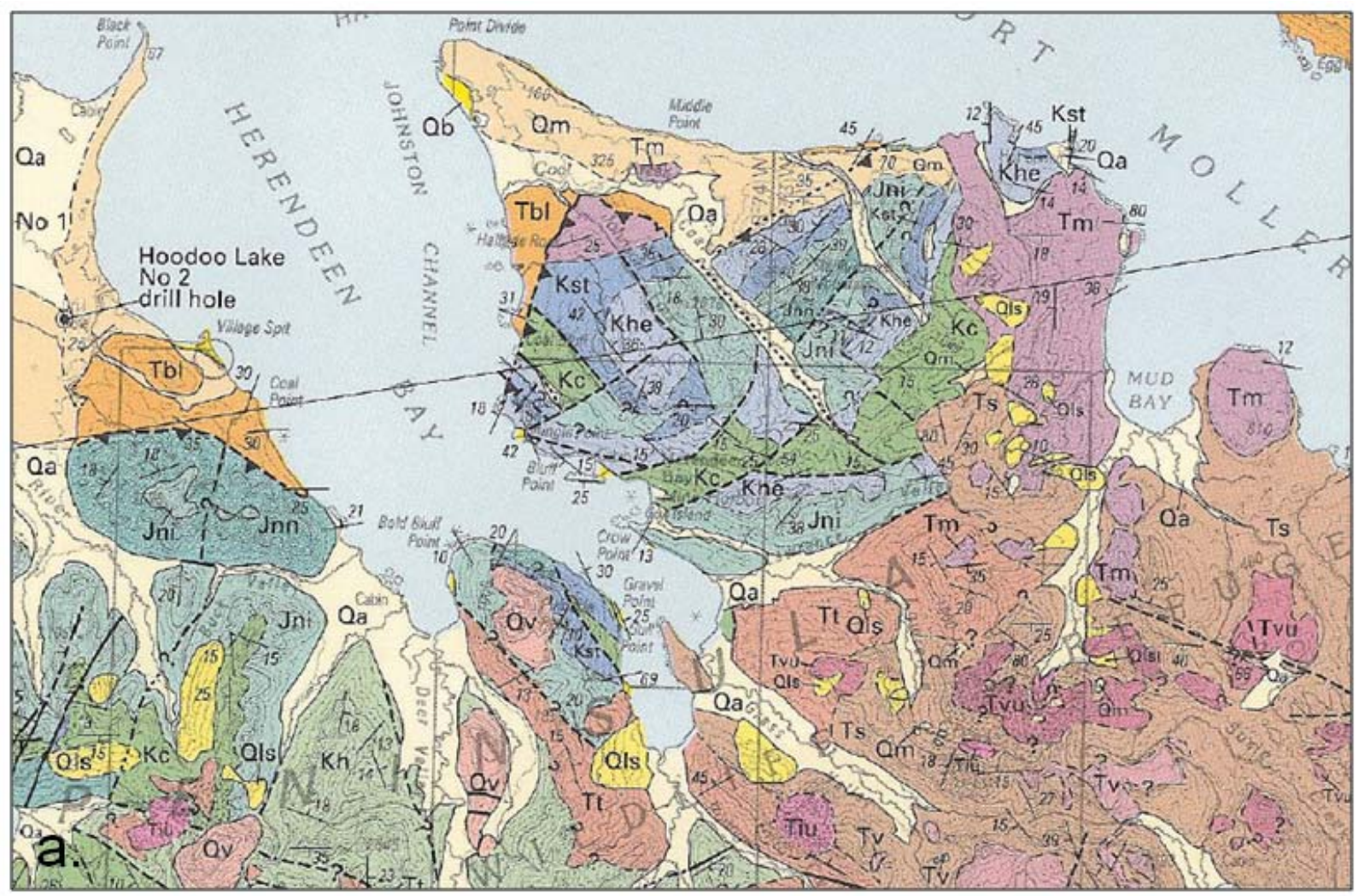

\section{WSW}

ENE

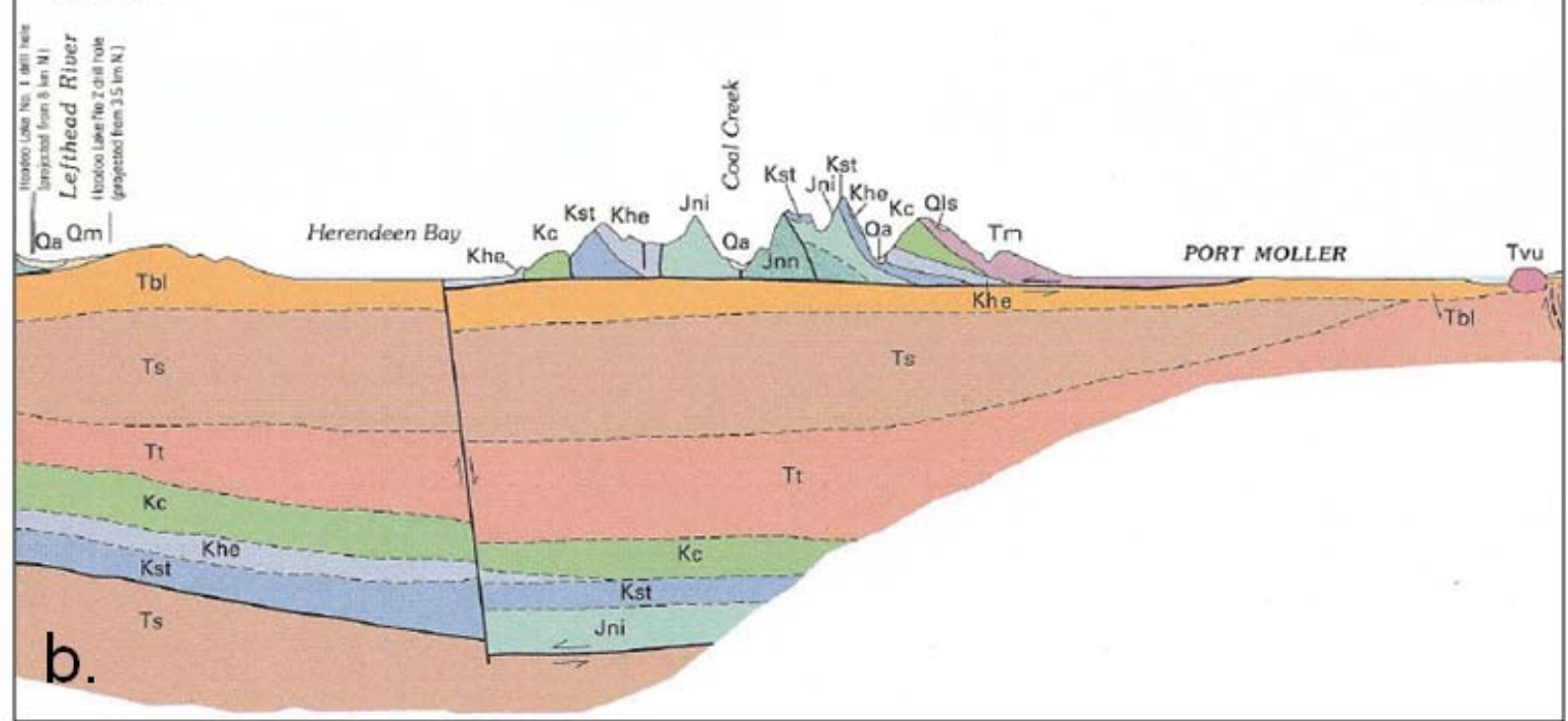

Figure 4. Excerpts from the 1:250,000-scale USGS geologic map (a) and cross section (b) of Wilson and others (1995) in the present study area in the Staniukovich peninsula-Herendeen Bay area. Note interpretation of subhorizontal overthrust placing a sheet consisting of complexly faulted blocks of Jurassic through Paleogene formations over units as young as Miocene Bear Lake Formation (see text for discussion). Compare to figs. 2, 3, and sheet 1. 
The Lower Cretaceous Staniukovich Formation has been variously defined by previous workers (Atwood, 1911; Burk, 1965; Detterman and others, 1996). As mapped in this study (sheet 1), the Staniukovich Formation is restricted to just the distinctive red-brown weathering, smooth-slope-forming siltstone and shale unit constituting most of the Staniukovich Shale originally defined by Atwood (1911). This fine-grained interval represents only the upper part of the Staniukovich Formation as redefined by Detterman and others (1996). Sandstones assigned to the lower part of the formation by Detterman and others (1996) could not be reliably differentiated in the field from lithologically similar, Buchia-rich sandstones of the upper Naknek Formation (Upper Jurassic), particularly in isolated or discontinuous exposures. These Buchia-rich sandstones are here mapped together with the Indecision Creek member (Detterman and others, 1996; Wilson and others, 1995; 1999) in the uppermost Naknek Formation.

The Lower Cretaceous Staniukovich and Herendeen formations are both absent west of Herendeen Bay. This absence might reflect non-deposition due to a local lack of accommodation space during Early Cretaceous time. It is equally possible that the formations were deposited and subsequently eroded west of Herendeen Bay during development of the regional mid-Cretaceous unconformity that underlies the Chignik Formation. During Late Cretaceous time, the area east of Herendeen Bay appears to have been more proximal than the area to the west. This is expressed lithostratigraphically by thick and widespread coarse conglomerates and coals in the Chignik Formation on the Staniukovich peninsula, compared with the thinner Chignik sandstones and time-equivalent sandy mudstones of the deeper water Hoodoo Formation southwest of Herendeen Bay.

\section{STRUCTURAL ELEMENTS}

The main structures that can be confidently recognized from the current mapping are large uplifts of folded and faulted Mesozoic strata. These include the northern part of the Sapsuk uplift west of Herendeen Bay and a more complex anticlinal uplift on the Staniukovich peninsula. These two areas differ strikingly in structural orientation, deformational style, and the northern limit of exposed Mesozoic rocks. This suggests that the map area can be meaningfully divided into two major structural domains here termed the Sapsuk domain to the west and the Staniukovich peninsula domain to the east. Each of these areas can be further subdivided north-to-south. The northern, low-relief coastal plain is underlain by Tertiary and Quaternary units on the south flank of the North Aleutian basin. The southern area has significant topography and is dominated by uplifted Mesozoic rocks.
The boundary between the eastern and western domains is concealed beneath Herendeen Bay. One highly speculative possibility is that Herendeen Bay itself could be controlled by a significant zone of down-to-west or left-lateral strike-slip faulting. Such a zone might represent the offshore continuation of the northweststriking, down-to-southwest faults near Pinnacle Peak, east of Deer Valley at the head of Herendeen Bay. An alternative explanation of the domain boundary will be discussed following a description of the structural style of each of the domains.

\section{SAPSUK DOMAIN}

The broad valleys and highland areas between Herendeen Bay and Sapsuk Lake (formerly named Hoodoo Lake) are dominated by Jurassic and Cretaceous rocks of the Sapsuk uplift. The lower hills and coastal plain to the north near the Hoodoo Lake Unit 1 and 2 wells (fig. 1) locally expose Miocene and younger units accommodated by subsidence at the southern edge of the North Aleutian basin. The southern limit of the Sapsuk domain extends eastward from the east end of Sapsuk Lake to Deer Valley. This excludes the majority of the Tertiary-Quaternary volcanic and hypabyssal intrusive rocks noted farther to the south by Wilson and others (1995). As noted above, we devoted less field time to work in the Sapsuk domain than the Staniukovich peninsula domain, so descriptions included here are based in part on our own field observations, partly on previous mapping (Burk, 1965; Amoco, 1979; Wilson and others, 1995), and partly on recent field observations and remote sensing interpretations of Sralla (2007).

The Sapsuk uplift is a broad, dominantly north-verging fault-cored structure with expansive dip panels of Jurassic and Cretaceous units (sheet 1, section A-A'). These Mesozoic rocks were emplaced above Miocene Bear Lake Formation by north-directed thrusting and/or reverse faulting, as evidenced in relatively continuous outcrops on the western shore of Herendeen Bay (fig. 5). The main fault, mapped here as a thrust, has a southerly dip of 45 degrees where a discrete slip surface was identified in shoreline outcrops. We have no evidence to constrain whether this fault becomes steeper or flatter with depth; Sralla (2007) interprets it as having an overall dip of 70 degrees to the south. Jurassic Naknek Formation in the hangingwall is intensely brecciated in a damage zone tens of meters thick. In a zone of similar thickness directly below the fault, Bear Lake strata were penetratively deformed in a semi-consolidated state by a combination of discrete shearing and plastic, fluidized granular flow. These exposures yielded no kinematic indicators to determine the sense of movement.

Approximately $3 \mathrm{~km}(1.8 \mathrm{mi})$ north of the main fault along the shoreline of Herendeen Bay, beds of the 
Bear Lake Formation are locally reverse faulted and asymmetrically folded. Slightly farther north, these compressional structures abruptly give way to an array of minor, mostly down-to-north normal faults (sheet 1 , section A-A'; Decker and others, 2005). This belt of up-to-south compressional and extensional faults north of the Sapsuk uplift is a segment of the David River zone (DRZ) (Amoco, 1979). Faulting within and adjacent to the DRZ is believed to include three kinematic components. First, there is a significant component of right-lateral strike-slip, which leads to transpressional uplift of the Black Hills west of the current study area (Worrall, 1991). Second, there is extensional subsidence of the basin to the north. Lastly, there is a component of orthogonal convergence, which leads to folding and reverse-faulting of the uplifted Mesozoic units to the south (Decker and others, 2005; Finzel and others, 2005).
The north-verging folds and thrusts involving Bear Lake Formation in this area are evidence of Late Miocene or younger compressional or transpressional deformation within and adjacent to the DRZ.

In the Mesozoic units of the hangingwall, Burk (1965) interpreted the Sapsuk uplift as a relatively simple northeast-trending fold, which he called the Hoodoo Lake anticline. More recently, Sralla (2007) reinterpreted it as a west-northwest-trending, doubly-plunging closure, which he called the Sapsuk Lake anticline. Its axis runs through the Quaternary-covered valleys southwest of Herendeen Bay. The names of several streams and lakes in this area were changed between the publication of Burk's (1965) map and the most recent USGS topographic base maps. In terms of current names (sheet 1), Naknek strata north of the lower Buck Valley and the upper forks of the Lefthead River constitute a gener-
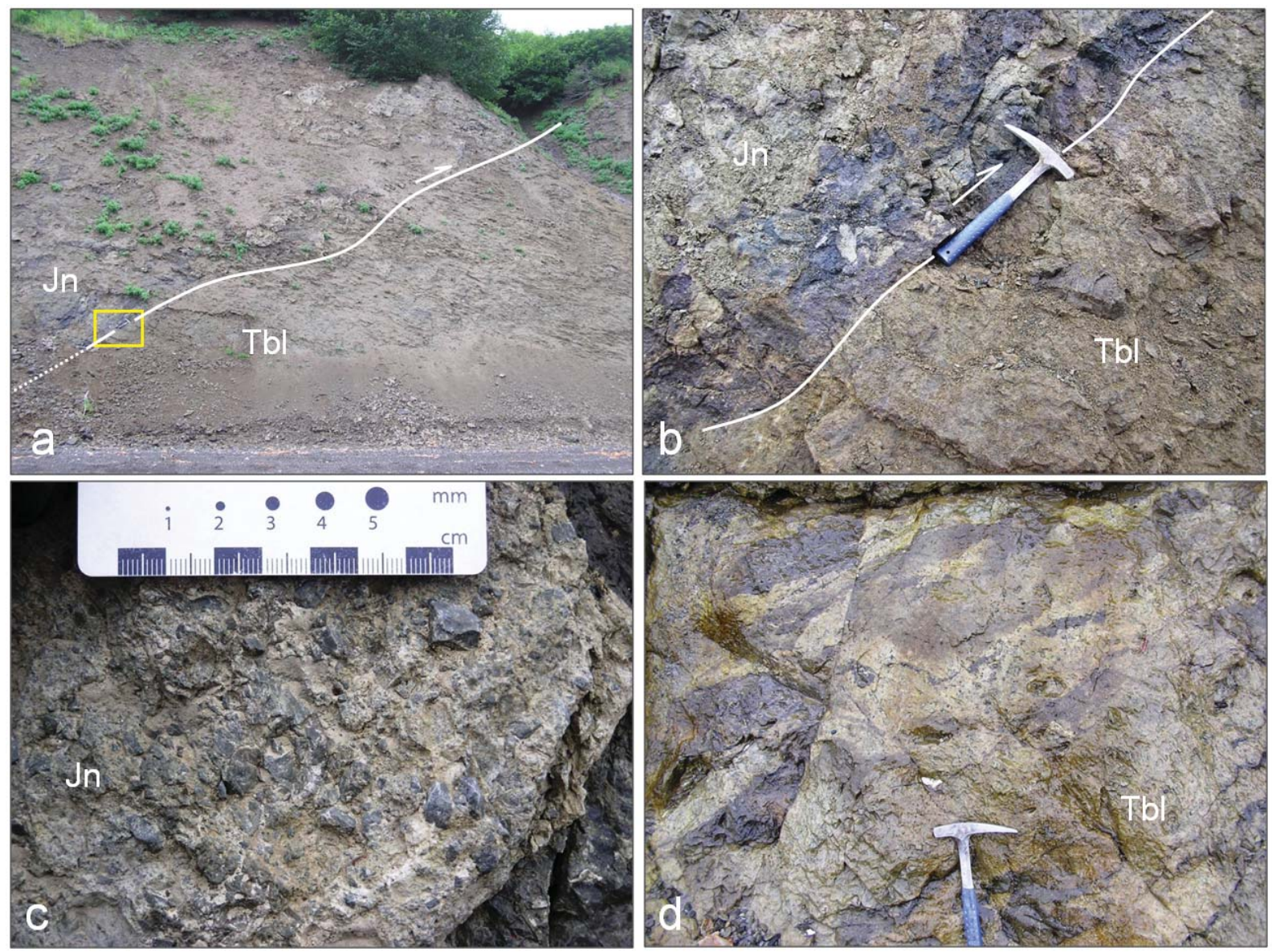

Figure 5. North-verging thrust or reverse fault exposed on western shore of Herendeen Bay places Jurassic Naknek Formation (Jn) over Miocene Bear Lake Formation (Tbl). Photograph in (a) gives outcrop-scale view; yellow rectangle indicates area of close-up in (b). Despite the broad damage zone involving both hangingwall and footwall units, there is remarkably little mixing of the formations across the discrete fault surface marked on the photos. Naknek Formation in the hangingwall is intensely brecciated at the centimeter scale (c), whereas Bear Lake Formation in the footwall tens of meters from the fault (d) was penetratively deformed in a semi-consolidated state, exhibiting characteristics of both discrete shearing and fluidized granular flow. 
ally north-dipping panel with inclinations of up to 20 degrees, whereas Naknek and Cretaceous rocks to the south make up a more gently south- to southeast-dipping panel (Burk, 1965; Sralla, 2007).

The maps of Amoco (1979) and Wilson and others (1995) do not plot an anticlinal axis for this uplift. Wilson and others (1995) showed fewer bedding attitudes than Burk (1965), and mapped most of the Naknek Formation in the highlands north of Buck Valley and the Lefthead River as belonging to the Northeast Creek member, which is stratigraphically lower than the uppermost Naknek Indecision Creek member south of the valleys. Wilson and others (1995) mapped a short east-westtrending fault segment, upthrown to the north. This fault may reconcile the occurrence of the oldest rocks in what is apparently the north flank of the uplift rather than at its core, as defined by the major reversal in dip direction between the northern and southern limbs. In an effort to honor the map unit distribution of Wilson and others (1995), we interpret this as an antithetic (south-verging) reverse fault (sheet 1 , section A-A'). However, without more detailed structural attitude constraints, it is difficult to determine whether this model can be bed-length balanced. Sralla (2007) noted that few faults crosscut the structure, and he interpreted the northern and southern dip panels as consisting of the same member of the Naknek Formation with no substantial fault between them (B. Sralla, oral commun., 2007).

Wilson and others (1995) mapped a cluster of several steep, north-northeast-trending faults at and beyond the southwest corner of our map area near Sapsuk Lake that were not field checked during the current study. As mapped, most show only minor vertical displacement of the Naknek and Chignik Formations, though one appears locally to have up to several hundred feet of stratigraphic separation. Burk (1965) mapped a single northeast-trending down-to-southeast normal fault in the same area. None of these faults were mapped as continuing across the wide valleys into the northern part of the Sapsuk uplift. In any case, they neither significantly disrupt nor compartmentalize the uplift's map pattern.

\section{STANIUKOVICH PENINSULA DOMAIN}

The Staniukovich peninsula between Port Moller and Herendeen Bay received considerably more attention during 2006 field studies than the area west of Herendeen Bay. Preliminary revised geologic mapping focused on developing a better understanding of the major structures in this area, which had been variously represented on previous geologic maps (figs. 2-4). The southern limit of the area described here extends east-northeastward from Deer Valley through Lawrence Valley to Mud Bay near the head of Port Moller, including the smaller peninsula made up of Pinnacle Peak and Bold Bluff Point at the south end of Herendeen Bay.

Perhaps the most obvious geologic features mapped on the Staniukovich peninsula (sheet 1) are the nearly orthogonal, relatively straight, northwest- and northeast-striking faults. Upon further inspection, the large-scale map pattern is that of a complexly faulted, northeast-southwest-trending system of anticlines and synclines (sheet 1 , map and section B-B'). This is a fundamental characteristic of the structure that is not fully expressed by the map or cross section of Wilson and others (1995; fig. 4). Situated immediately south of the coastal plain, the Staniukovich Mountain anticline is the most prominent fold in this area, exposing a thick succession of Upper Jurassic to Lower Cretaceous Naknek and Staniukovich formations in its core. The anticline clearly deforms all units as young as the Upper Cretaceous Chignik Formation. The relationship of Tertiary formations to the folding is less clear, as will be discussed in more detail below.

Burk (1965) and Amoco (1979) depicted the Staniukovich Mountain anticline as a fairly simple northeast-southwest elongated, doubly-plunging closure with only minor complication due to a few steep, northeaststriking (longitudinal) faults (figs. 2, 3a). Amoco (1983) recognized additional steep faults, including several important northwest-striking (transverse) faults that offset the fold axis (fig. 3b). Wilson and others (1995) mapped the area as having still greater fault complexity, showing numerous intersecting strands of two nearly orthogonal fault sets (fig. 4a). These USGS workers further proposed the existence of a large-displacement, low-angle thrust fault, which they believed transported highly disrupted blocks of Mesozoic and Paleogene rocks above little-deformed Neogene footwall strata throughout most of the peninsula (fig. 4b; Wilson and others, 1995; Detterman and others, 1996). Our mapping (sheet 1) recognizes an even greater number of steep, northeast- and northwest-trending faults, but we find no evidence to support the interpretation of major low-angle thrusting on the Staniukovich peninsula.

Faults and shear fractures measured in the Naknek, Staniukovich, Herendeen, and Chignik Formations on the Herendeen Bay shoreline (fig. 6) reflect the two dominant fault trends reflected in the map pattern (sheet 1). Most faults in these populations are steep to moderately dipping. Fault striae indicate that most are oblique-slip faults, with a locally dominant component of strike-slip. Several of the poorly exposed transverse faults that control major northwest-trending drainages are interpreted from stratigraphic juxtapositions to have a significant component of dip-slip. These transverse faults compartmentalize the core and northwestern limb of the Staniukovich Mountain anticline into discrete 
segments marked by varying position and plunge of fold axes, offset positions of the oldest exposed strata, and the type and density of faulting. We interpret them as early-formed tear faults that allowed each sector to respond to further deformation quasi-independently of adjacent compartments. The fold axis has apparent right-lateral separation of nearly $2.5 \mathrm{~km}(1.5 \mathrm{mi})$ across Coal Valley, and approximately $1.3 \mathrm{~km}(0.8 \mathrm{mi})$ across Johnson Fork. The fact that the map pattern is not only laterally offset, but also exposes older stratigraphic units on the northeastern sides of these valleys, indicates that the net slip includes a component of down-to-southwest vertical separation.

The southwestern half of the Staniukovich Mountain anticline is dissected by numerous intersecting transverse and longitudinal fault segments that partition this end of the structure into as many as a dozen mappable blocks. Near the center of the anticline in the block of Naknek and Staniukovich Formations bounded by transverse faults along Coal Valley and Johnson Fork, bedding attitudes indicate the fold axis plunges to the northeast. Immediately to the south, the large block

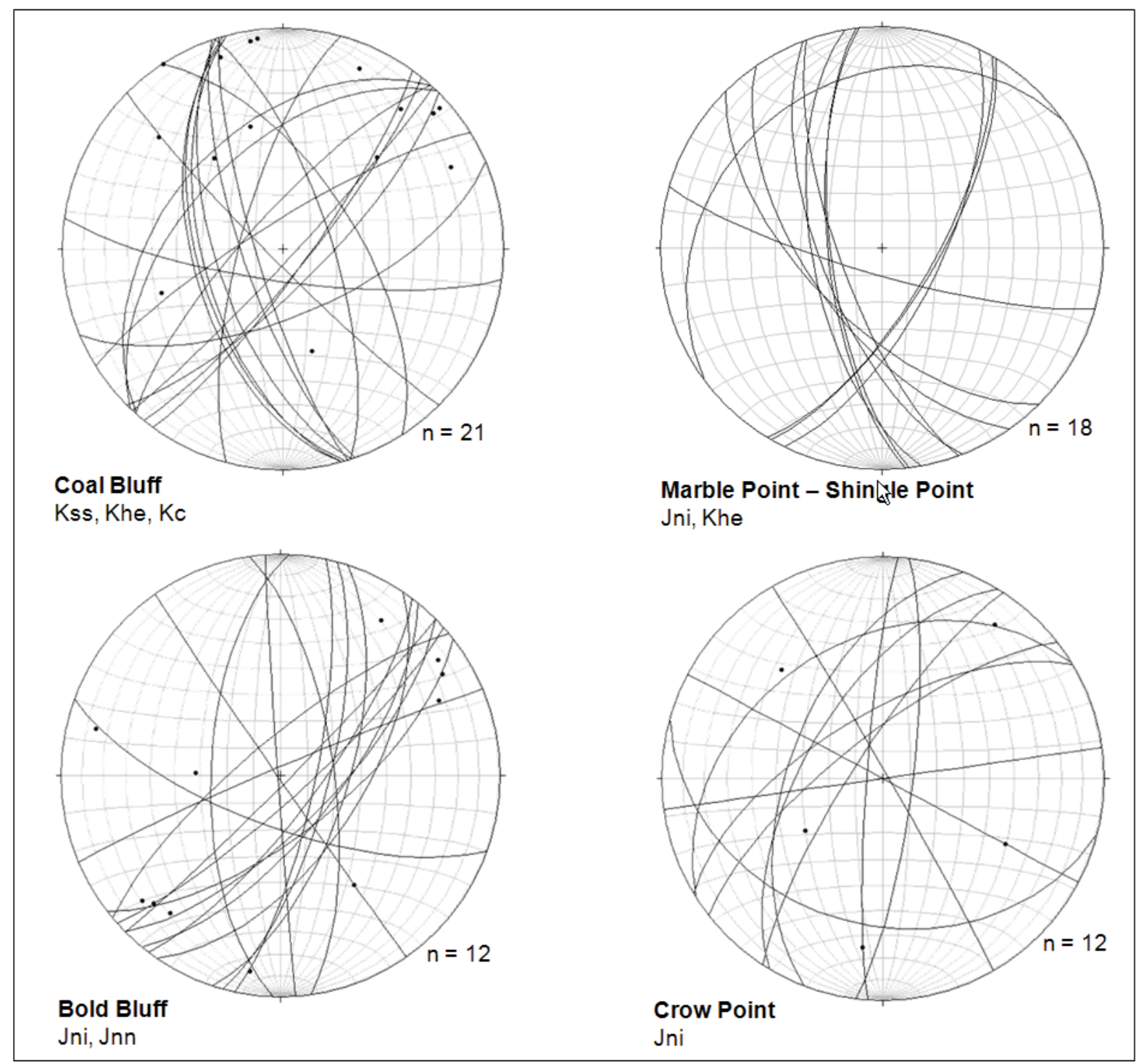

Figure 6. Stereograms of faults (and shear fractures), and slickenside striae in shoreline outcrops, eastern and southern Herendeen Bay. Faults (great circles) are mostly steeply dipping, northeast and northwest striking. Slickenside striae (dots) are mostly gently to moderately plunging, indicating a predominance of oblique-slip faults with a strong strike-slip component. See sheet 1 for localities represented by these populations. Map unit abbreviations as follows: Kc = Chignik Formation, Kss $=$ Staniukovich Formation, Khe = Herendeen Formation, Jni = Indecision Creek member of Naknek Formation, Jnn = Northeast Creek member of Naknek Formation. 
between Lynden Creek and Johnson Fork presented a structural paradox as mapped previously (Wilson and others, 1995), in which a broad, generally synclinal depression cored by Herendeen Formation was mapped at the center of the larger anticline. Based on our observations in this fault-bounded block, we reinterpret it a northeast-plunging anticlinal segment similar to the one just to the north, but with much less Naknek and Staniukovich exposed in its core to the southwest, plunging beneath a broad area of Chignik Formation outcrop to the northeast (sheet 1).

At the far western end of the Staniukovich Mountain anticline, many hilltops have only rubble-crop exposures, rendering the highly compartmentalized fault pattern somewhat interpretive, but mutually cross-cutting relationships suggest that these orthogonal fault sets developed concurrently rather than sequentially. Southwestern plunge beneath Herendeen Bay is most apparent from gentle to moderate southwest dip in the Herendeen Formation along the shoreline between Bluff Point and Marble Point.

The northeastern half of the Staniukovich Mountain anticline is cut by fewer faults than the southwestern half. The major faults recognized in this part of the fold are northeast-striking longitudinal faults that are nearly vertical to steeply southeast-dipping and downthrown to the southeast. A few faults oriented transverse and oblique to the fold axis are interpreted to intersect these longitudinal faults east of Staniukovich Mountain, creating a triangular compartment near the crest of the anticline. In this half of the anticline, the overall convergence of the younger units on the flanks suggests northeast plunge. However, northeast of the unnamed drainage east of Staniukovich Mountain, the axis locally appears to plunge gently in the opposite direction (toward the southwest). The maps of Burk (1965) and Wilson and others (1995) present conflicting strike and dip data in Tertiary lava flows unconformably overlying Mesozoic units near the northeastern end of the anticline on the eastern side of the peninsula, and plunge could not be determined.

The southeastern flank of the Staniukovich Mountain anticline is bounded by a series of relatively continuous longitudinal faults, upthrown relative to the adjacent belt of Chignik Formation in the core of the synclinal trough informally referred to here as the Mine Harbor syncline. This faulted contact is not well exposed between Mine Harbor and Coal Valley, but the curved map trace suggests it is a northwest-dipping reverse fault (sheet 1 , section B-B'). Burk (1965) mapped this structure as a southeast-dipping normal fault. Northeast of Coal Valley, the contact between Chignik and older units is at a very steep, locally anastomosed fault zone, where one fault splays into two sub-parallel strands that continue more than $5 \mathrm{~km}$ (3 mi) to the northeast, separated by just a few hundred meters.

The Mine Harbor syncline is also fault-bounded on its southern side, where the upthrown northern limb and core of the narrow Lawrence Valley anticline exposes Herendeen, Staniukovich, and Naknek Formations. These bounding faults are locally well exposed, but their map traces are only approximately located for much of their length, so their dip and dip directions are uncertain. Burk (1965) mapped this southern edge of the Chignik belt as a single normal fault; we recognize several fault segments, and consider them more likely to have reverse or reverse-oblique displacement. Cretaceous strata are not exposed on the southern limb of the Lawrence Valley anticline; the valley follows a longitudinal fault juxtaposing the Jurassic core against lower Tertiary Tolstoi Formation.

Our remapping finds no positive cross-cutting relationships on the Staniukovich peninsula that demonstrate the late Miocene or younger compressional or transpressional deformation seen in the Sapsuk domain. The contact between Mesozoic and Tertiary units in coastal plain and shoreline outcrops on the northwest flank of the Staniukovich Mountain anticline is mostly covered. It was mapped as conformable by Burk (1965), but was interpreted by Amoco $(1979,1983)$ as multiple parallel or splayed strands of up-to-south faults of the David River zone (DRZ). We map two exposed faults (and one concealed fault) that strike northeast and have down-to-north separation in outcrops on the peninsula's northern shoreline. Following Amoco's lead, we extrapolate this fault system westward along the topographic break between the elevated Mesozoic rocks and the Tertiary rocks of the coastal plain as the probable eastern extension of the David River zone (sheet 1, map and section B-B'). These DRZ faults are evident in coastal outcrops of Chignik and Meshik formations, and are inferred to cut the Stepovak and Bear Lake Formations here as well. The generally northwest dip of Tertiary units in the northern part of the peninsula is conformable with the northwest limb of the Staniukovich Mountain anticline. However, at least some of this dip may relate to extensional faulting and subsidence of the basin to the north rather than solely to compressional uplift and folding to the south.

Relative and radiometric ages from volcanic rocks do provide some constraints on the timing of deformation on the Staniukovich peninsula. Lavas yielding late Middle Eocene to Oligocene radiometric ages (30.2-38.0 Ma) are assigned to the Meshik series, whereas porphyritic volcanics south of Herendeen Bay, capping Pinnacle Peak and the ridge to the southwest, yield Quaternary ages (0.67-0.86 Ma; Wilson and others, 1994, 1995). Of the Meshik exposures, the isolated ridge of columnar 
jointed andesite on the southwestern side of Johnson Fork is the youngest, at $30.2 \mathrm{Ma}$ (Wilson and others, 1994). This rock unit is surrounded by cover and Quaternary sediments, and its fault juxtaposition with folded Mesozoic rocks (sheet 1 ) is only speculative. Better cross-cutting relationships are apparent on the east side of the peninsula, where Meshik volcanics dated within a narrow Middle to Late Eocene age range of 36.1-38.0 Ma (Wilson and others, 1994) unconformably overlie the folded Chignik, Herendeen, and Naknek Formations. Southwest of Mud Bay, Meshik flows exhibit moderate to gentle northeasterly dip that probably reflects substantial paleotopographic relief on the pre-Meshik unconformity. Strike and dip measurements in these lavas are highly variable, and it is difficult to determine whether folding continued after extrusion of the lavas. Clearly, there has been at least local uplift since Late Eocene time; 36.5 Ma leuco-basalt flows interbedded with oyster-bearing volcaniclastic beds (Wilson and others, 1994, sample 84ACe 177) were deposited at or below sea level, but now reside at an elevation of approximately $350 \mathrm{~m}(1,150 \mathrm{ft})$.

Current mapping revealed no evidence for the lowangle late Miocene or younger thrust fault inferred by USGS geologists to place Mesozoic units and locally, Meshik volcanics above Bear Lake Formation across most of the Staniukovich peninsula (fig. 4b; Wilson and others, 1995; 1999; Detterman and others, 1996). The exposures they mapped as Miocene Bear Lake Formation (Wilson and others, 1995; 1999; Detterman and others, 1996, fig. 10) or considered to be "unassigned Tertiary strata" (Detterman and others, 1996, p. 31) at Coal Bluff on the eastern shore of Herendeen Bay are mapped here with a high degree of confidence as Chignik Formation (sheet 1), mostly because of the highly distinctive pebble-cobble conglomerates with pink granitoid clasts containing large, euhedral, zoned potassium feldspar phenocrysts. We concur with Burk's (1965) and Amoco's $(1979,1983)$ mapping of these exposures as Chignik Formation in normal stratigraphic position unconformably overlying the Herendeen Formation. Efforts to locate exposures of Bear Lake Formation mapped by Wilson and others (1995) in the lower plate of their thrust beneath the low ridge of Meshik volcanics near the mouth of Johnson Fork (sheet 1) yielded no exposed bedrock. Furthermore, examination and measurement of numerous fault surfaces in good exposures at Coal Bluff and Marble Point, where the inferred thrust should be most apparent, revealed only steep, oblique- and strikeslip faults, and no observations of low-angle thrusts.

In summary, at least two phases of deformation are recognizable in the Staniukovich peninsula domain. Folding and high-angle faulting of Upper Cretaceous and older strata prior to late Middle Eocene time gave rise to the angular unconformity below the Meshik flows and equivalent Stepovak Formation volcaniclastic strata on the eastern part of the peninsula. Further deformation since Late Eocene time has locally resulted in at least $350 \mathrm{~m}(1,150 \mathrm{ft})$ of local uplift. This phase of Tertiary uplift might correspond to Late Miocene or younger reverse faulting and folding in the Sapsuk domain, but we find no evidence of thrusting with large horizontal displacement on the Staniukovich peninsula.

\section{STRUCTURAL TRAP POTENTIAL}

Though we have not mapped it in detail, the thrustcored Sapsuk uplift appears to exhibit considerably less structural complexity than the intensely faulted, compartmentally-deformed Staniukovich Mountain anticline and the adjacent syncline-anticline pair to the south. Though both areas face significant risks relative to reservoir and seal facies, the broad, gently dipping panels of the Sapsuk uplift may present more favorable conditions for structural trapping. However, this depends on whether there is, in fact, a significant fault near the axis and also depends on there being adequate plunge in both directions. The thick Naknek-Bear Lake gouge zone at the thrust in the north limb of the Sapsuk uplift would very likely provide adequate seal for fault-bounded hydrocarbon accumulations in either the hangingwall or footwall.

Our remapping of the Staniukovich Mountain anticline suggests it is unlikely to behave as a single dome-like trap. More importantly, we consider it highly unlikely that the Mesozoic to Paleogene units at the surface have been thrust-emplaced over little-deformed Tertiary formations. Many of its fault-bounded blocks may harbor potential traps defined by two-way or threeway dip combined with a fault buttress component. In these cases, trap integrity will thus depend on the adequacy of fault seals, which can be compromised by high sandstone:mudstone ratios in the faulted strata, and by reactivation of structures after hydrocarbon migration. If effective fault seals are present in the subsurface, the Staniukovich Mountain anticline would likely host a number of smaller compartmentalized accumulations rather than a single accumulation defined by the larger fold geometry.

\section{STRUCTURAL MODEL}

The fundamental reason for the very different types, orientations, and densities of faulting in uplifted Mesozoic units in the Sapsuk and Staniukovich peninsula domains on opposite sides of Herendeen Bay remains a matter of speculation. Both uplifts are interpreted as immediately adjacent to the east-west-trending southern margin of the North Aleutian basin. This boundary belt (the DRZ) likely has a complex structural history involving compression to the south, extension to the north, 
and a mix of right lateral strike-slip, reverse-oblique (transpression) and normal-oblique (transtension) within it. It is also probable that different segments of this belt have been dominated by different styles of deformation. Strain within transpression zones is commonly partitioned into domains dominated by strike-slip (plane strain, rotational simple shear) and compression (non-rotational pure shear) (for example, Schreurs and Colletta, 2002; Jones and Tanner, 1995; Clegg and Holdsworth, 2005). Outcrop fracture orientation data suggest the ratio of strike-slip to normal convergence increases westward along the DRZ from Herendeen Bay (Decker and others, 2005), and that the Sapsuk uplift area may be dominated by normal convergence.

The fault system in the Staniukovich peninsula domain is similar to that generated in analog models of restraining oversteps in strike-slip fault regimes (fig. 7; McClay and Bonora, 2001). This suggests uplift may be related to transfer of dextral slip from the Sapsuk domain segment of the DRZ to an as-yet unidentified northerly segment beneath Port Moller and farther east. In this context, the Staniukovich Mountain uplift can be interpreted as a broad, antiformal pop-up or positive flower structure, in which the combination of wrenching and shortening generates a more complex pattern of transverse and longitudinal faults, offset fold axes, and compartmentalized blocks than is recognized in the Sapsuk uplift to the west.

As stated previously, the boundary between the Sapsuk and Staniukovich peninsula domains could be a fault hidden beneath Herendeen Bay. The restraining overstep models of McClay and Bonora (2001) suggest an alternative explanation, that the domain boundary may simply reflect the margin of the uplift that develops in the overstep zone, where displacement transfer causes an abrupt change in the orientation, types, and density of

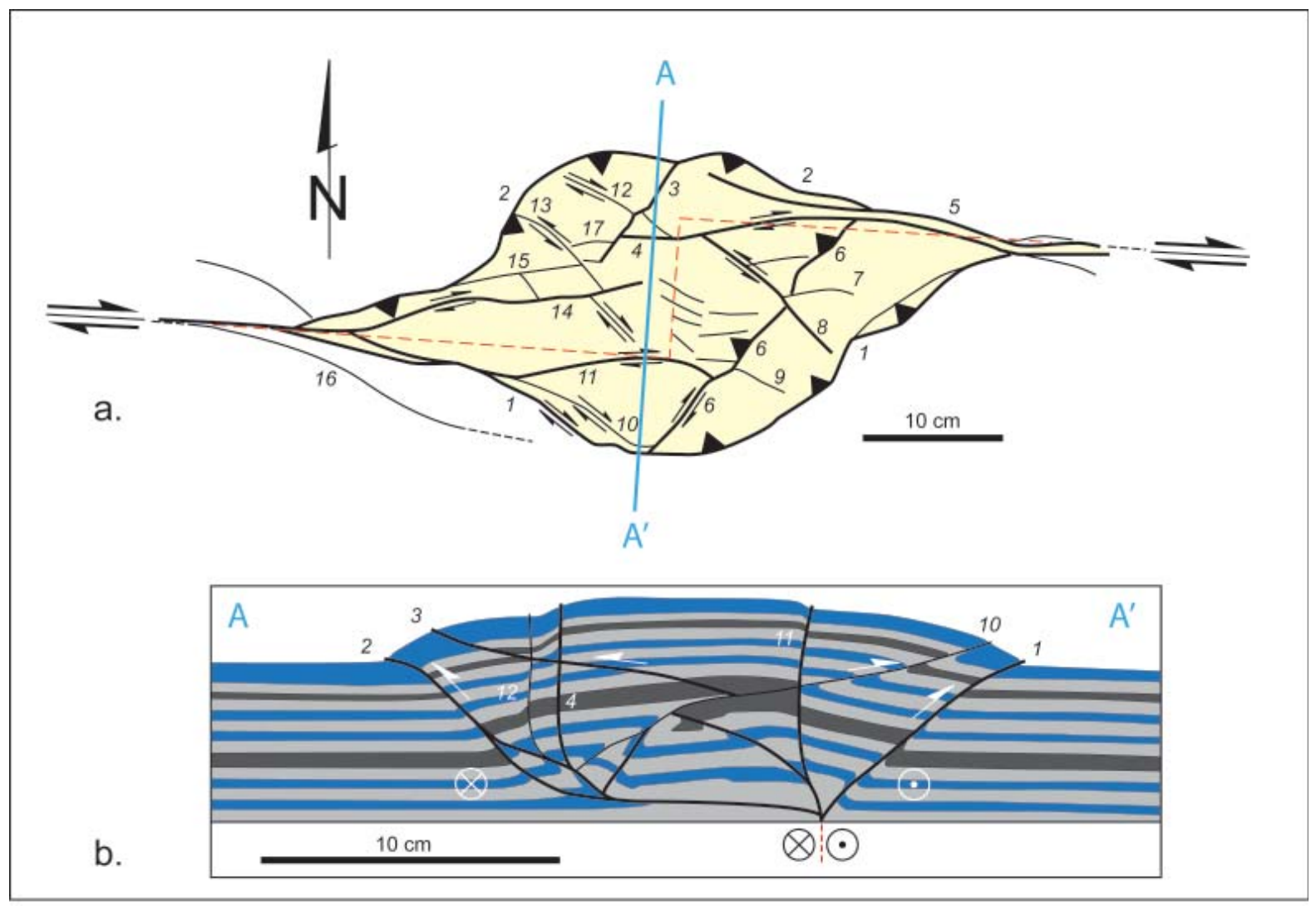

Figure 7. Structural patterns in the Staniukovich peninsula domain have much in common with uplift structures generated in analog modeling of restraining oversteps in strike-slip systems. The plan view (a) and enlarged cross section (b) have been rotated and redrawn in mirror image from the originals (McClay and Bonora, 2001, fig. 6) to show them as they would appear had they been derived from right-lateral instead of left-lateral models to facilitate comparison to the present study area (sheet 1). The overstep is the zone in which strain is transferred between the main strike-slip faults (red dashed lines), which in this case have zero overlap at their tips. Symbols in model cross section mark displacement away $\otimes$ from viewer and toward $\odot$ viewer. Note the northeast-southwest elongated rhomboidal uplift accommodated by northwest-and southeast-verging reverse-oblique faults, and the development of transverse faults with both right and left lateral slip that compartmentalize the overall uplift into differentially uplifted blocks. 
faults and folds. The multiple phases of deformation that have affected this area may well have been accompanied by significant changes in the greater tectonic regime. In this case, it would be unrealistic to expect all the structures to conform to a single suite of structural styles predicted by a given single-stage analog model.

\section{CONCLUSIONS}

Recent field investigations have resulted in substantial revision of pre-existing geologic mapping in the vicinity of recent oil and gas leasing in the Staniukovich peninsula-Herendeen Bay area. Although preliminary in nature, this remapping provides a basis for describing important variations in structural orientation and style, interpreting the deformation history, and addressing the area's hydrocarbon resource potential.

West of Herendeen Bay, the Sapsuk domain is dominated by a large, west-northwest-trending, thrustor reverse-fault-bounded uplift that places Mesozoic rocks in fault contact with Miocene Bear Lake Formation. Sralla (2007) interpreted this uplift as a broad, doubly-plunging anticline devoid of significant fault complications. The map pattern (sheet 1), although inadequately constrained by attitude data, is consistent with this uplift having long, gently- to moderately-dipping flanks. However, the question of whether different members of the Naknek Formation are juxtaposed by faulting near the axis of the structure has implications regarding trap integrity, and merits further investigation. The northward transition from compressional to extensional faulting in the Bear Lake Formation in the coastal belt of the Sapsuk domain reflects syndepositional Miocene subsidence of the offshore North Aleutian backarc basin.

Between Herendeen Bay and Port Moller, the Staniukovich peninsula domain consists of a series of complexly faulted, northeast- to east-northeast-trending folds, including the Staniukovich Mountain anticline, the Mine Harbor syncline, and the Lawrence Valley anticline. Previous workers viewed the Staniukovich Mountain anticline as either a relatively simple dome "broken by several longitudinal and traverse faults" (Burk, 1965, p. 128) or as a chaotic sheet of allochthonous blocks emplaced on nearly undeformed Jurassic through Miocene units (Wilson and others, 1995). Our mapping and structural observations lead us to conclude instead that this structure is best viewed as an extensively faulted basement-cored composite uplift in which numerous compartments developed early on and have responded to continued deformation quasi-independently of one another. As in the Sapsuk domain, the northern coastal plain of the Staniukovich peninsula is underlain by down-to-north faults that mark the northward transition from onshore uplift to offshore subsidence.
Most faults in the map area are relatively steep as indicated by relatively straight map traces and fault fabric measurements. In the Staniukovich peninsula domain, slickenlines indicate a prevalence of obliqueslip movement, and cross-cutting relationships document the co-evolution of the northeast-southwest- and northwest-southeast-trending fault sets that compartmentalize structures.

The structural styles, orientations, and differences between the two domains are consistent with deformation in a right-lateral oblique-convergent setting. The domains may represent different segments of the eastward continuation of the dextral transpressive David River zone as it approaches a left-stepping restraining overstep. In this model, the Sapsuk domain exhibits relatively simple right-lateral transpressional structure along the DRZ, whereas the Staniukovich peninsula domain exemplifies the more complex faulting and folding characteristic of the rhomboidal uplift zone within the restraining overstep itself. Radiometric dating and cross-cutting relationships document at least two main deformational phases in the map area. Substantial folding and faulting occurred on the Staniukovich peninsula between Late Cretaceous and late Middle Eocene time. Subsequent uplift of at least $350 \mathrm{~m}$ is locally documented in this domain, and may be related to late Miocene or younger reverse faulting in the Sapsuk uplift.

The extensive folding and high-angle faulting documented at the surface in the map area suggests a high likelihood that there are structural trapping configurations for hydrocarbons in the subsurface, most of which likely include a fault buttress component. The prevalence of sandstones and conglomerates relative to fine-grained sealing lithologies, considered alongside the area's multi-phase deformation history, suggests many faults may not be reliably sealed. Given the presence of effective fault seals, the structurally compartmentalized Staniukovich Mountain anticline is more likely to host multiple smaller accumulations than a single large oil and gas field.

\section{ACKNOWLEDGMENTS}

Fieldwork for this study was conducted during 2005 and 2006 with funding from multiple sources, including a U.S. Department of Energy grant from the Arctic Energy Technology Development Laboratory at the University of Alaska Fairbanks to Rocky Reifenstuhl (program head) and Paul McCarthy (principal investigator, UAF), Bristol Bay Native Corporation, and Division of Geological \& Geophysical Surveys and Division of Oil and Gas operating and capital improvement project budgets. The authors thank Bryan Sralla for valuable technical discussions. The text, figures, and map benefited from insightful reviews by Robert Swenson and Rick Levinson. 


\section{REFERENCES CITED}

Allison, R.C., and Addicott, W.O., 1973, The Mytilusmiddendorffi group (Bivalvia) of the North American Miocene [abs.]: Geological Society of America Abstracts with Programs, v. 5, p. 2-3.

Amoco, 1979, Geologic map of the Alaska Peninsula: Amoco Production Company Geologic Report FR02-79, (unpublished report of 1977 field season, available through Alaska Geologic Materials Center), scale 1 in = 16,000 ft (1:192,000).

_ 1983, Geologic map of the Staniukovich Mountain area: Amoco Production Company Geologic Report FW-18-81R, (unpublished report of 1981 field season, available through Alaska Geologic Materials Center), scale 1:63,360.

Atwood, W.W., 1911, Geology and mineral resources of parts of the Alaska Peninsula: U.S. Geological Survey Bulletin 467, 137 p.

Brockway, Ronald, Alexander, B., Day, P., Lyle, W.M., Hiles, R., Decker, W., Polski, W., and Reed, B.L., 1975, Bristol Bay region, stratigraphic correlation section, southwest Alaska: Anchorage, The Alaska Geological Society, 1 sheet.

Burk, C.A., 1965, Geology of the Alaska Peninsula-Island Arc and Continental Margin: The Geological Society of America Memoir 99, 250 p., 3 sheets.

Clegg, P., and Holdsworth, R.E., 2005, Complex deformation as a result of strain partitioning in transpression zones; an example from the Leinster Terrane, SE Ireland: Journal of the Geological Society, v. 16.2, p. 187-202.

Decker, P.L., Finzel, E.S., Ridgway, K.D., Reifenstuhl, R.R., and Blodgett, R.B., 2005, Preliminary summary of the 2005 field season; Port Moller, Herendeen Bay, and Dillingham areas, Bristol Bay Basin, Alaska Peninsula: Alaska Division of Geological \& Geophysical Surveys Preliminary Interpretive Report 2005-7, 55 p., 2 sheets.

Detterman, R.L., 1978, Interpretation of depositional environments in the Chignik Formation, Alaska Peninsula, in Johnson, K.M., ed., The United States Geological Survey in Alaska; Accomplishments during 1977: U.S. Geological Survey Circular 772-B, p. B62-B63.

Detterman, R.L., and Reed, B.L., 1980, Stratigraphy, structure, and economic geology of the Iliamna Quadrangle, Alaska: U.S. Geological Survey Bulletin 1368-B, 86 p., 1 plate, scale 1:250,000.

Detterman, R.L., Case, J.E., Miller, J.W., Wilson, F.H., and Yount, M.E., 1996, Stratigraphic framework of the Alaska Peninsula: U.S. Geological Survey Bulletin 1969-A, 74 p.
Detterman, R.L., Miller, T.P., Yount, M.E., and Wilson, F.H., 1981, Geologic map of the Chignik and Sutwik Island quadrangles, Alaska: U.S. Geological Survey Miscellaneous Investigations Series Map I-1229, scale 1:250,000.

Dubois, G.D., Wilson, F.H., and Shew, N.B., 1987, Potassium-argon age determinations from the Port Moller and Stepovak Bay quadrangles, Alaska Peninsula: U.S. Geological Survey Open-File Report 87-191, 1 plate, scale 1:250,000.

Fairchild, D.T., 1977, Paleoenvironments of the Chignik Formation, Alaska Peninsula: Fairbanks, Alaska, University of Alaska Fairbanks, M.S. thesis, 168 p.

Finzel, E.S., Reifenstuhl, R.R., Decker, P.L., and Ridgway, K.D., 2005, Sedimentology, stratigraphy, and hydrocarbon reservoir-source rock potential, using surface and subsurface data, of Tertiary and Mesozoic strata, Bristol Bay Basin and Alaska Peninsula: Alaska Division of Geological \& Geophysical Surveys Preliminary Interpretive Report 2005-4, 67 p.

Galloway, W.E., 1974, Deposition and diagenetic alteration of sandstone in northeast Pacific arc-related basins; Implications for graywacke diagenesis: Geological Society of America Bulletin, v. 85, no. 3, p. 379-390.

Gillis, R.J., Reifenstuhl, R.R., Decker, P.L., Strauch, A.L., and Helmold, K.P., 2007, Onshore Alaska Peninsula petroleum system assessment: preliminary summary of outcrop studies of the Port Moller area, 2006 [abs]: American Association of Petroleum Geologists Bulletin, v. 91, Annual Meeting Program Abstracts (digital), http://www.searchanddiscovery. net/documents/2007/07018annual_abs_Ingbch/abstracts/ lbGillis.htm.

Jones, D.L., and Detterman, R.L., 1966, Cretaceous stratigraphy of the Kamishak Hills, Alaska Peninsula, in Geological Survey research 1966, Chapter D: U.S. Geological Survey Professional Paper 550-D, p. D53-D58.

Jones, R.R., and Tanner, P.W.G., 1995, Strain partitioning in transpression zones: Journal of Structural Geology, v. 17, p. 793-802.

Knappen, R.S., 1929, Geology and mineral resources of the Aniakchak district: U.S. Geological Survey Bulletin 797, p. 161-223.

Mancini, E.A., Deeter, T.M., and Wingate, F.H., 1978, Upper Cretaceous arc-trench gap sedimentation on the Alaska Peninsula: Geology, v. 6, p. 437-439.

Marincovich, Louie, Jr., 1983, Molluscan paleontology, paleoecology, and North Pacific correlations of the Miocene Tachilni Formation, Alaska Peninsula, Alaska: Bulletin of American Paleontology, v. 84, no. 317, p. 59-155, plates 12-23. 
McClay, K., and Bonora, M., 2001, Analog models of restraining stepovers in strike-slip fault systems: American Association of Petroleum Geologists Bulletin, v. 85, p. 233-260.

Nilsen, T.H., 1984, Miocene back-arc tidal deposits of the Bear Lake Formation, Alaska Peninsula, in Reed, K.M., and Bartsch-Winkler, Susan, eds., The United States Geological Survey in Alaska; Accomplishments during 1982: U.S. Geological Survey Circular 939, p. 85-88.

Palache, Charles, 1904, Geology about Chichagof Cove, Stepovak Bay; with notes on Popof and Unga Islands (Alaska): Harriman Alaska Expedition, v. 4, p. 69-88.

Schreurs, G., and Colletta, B., 2002, Analog modelling of continental transpression, in Schellart, P., and Passchier, C., eds., Analogue modelling of large-scale tectonic processes: Journal of the Virtual Explorer, v. 7., p. 67-78.

Spurr, J.E., 1900, A reconnaissance in southwestern Alaska in 1898: U.S. Geological Survey 20th Annual Report, Part 7, p. 31-264.

Sralla, Bryan, 2007, Structural geometry, kinematics, and hydrocarbon exploration potential of Sapsuk Lake anticline, Herendeen Bay region, Alaska Peninsula [abs]: Alaska Geology, v. 38, no. 1, p. 1-2.

Wilson, F.H., 1985, The Meshik arc-An Eocene to earliest Miocene magmatic arc on the Alaska Peninsula: Alaska Division of Geological \& Geophysical Surveys Professional Report 88, 14 p.

Wilson, F.H., and Shew, N., 1992, Map and tables showing geochronology and whole-rock geochemistry of selected samples, Ugashik and part of Karluk quadrangles, Alaska: U.S. Geological Survey Miscellaneous Field Studies Map MF-1539-E, 12 p., 1 plate, scale $1: 250,000$.
Wilson, F.H., Detterman, R.L., and DuBois, Gregory, 1999, Digital data for the geologic framework of the Alaska Peninsula, Southwest Alaska, and the Alaska Peninsula Terrane: U.S. Geological Survey OpenFile Report 99-317, 41 p., 1 plate, scale 1:500,000, http://wrgis.wr.usgs.gov/open-file/of99-317.

Wilson, F.H., Detterman, R.L., Miller, J.W., and Case, J.E., 1995, Geologic map of the Port Moller, Stepovak Bay, and Simeonof Island quadrangles, Alaska Peninsula, Alaska: U.S. Geological Survey Miscellaneous Investigations Series Map I-2272, 2 plates, scale $1: 250,000$.

Wilson, F.H., Shew, N., DuBois, G.D., and Bie, S.W., 1994, Sample locality map and analytical data for potassium-argon ages in the Port Moller, Stepovak Bay, and Simeonof Island quadrangles, Alaska Peninsula: U.S. Geological Survey Miscellaneous Field Studies Map MF-2155-E, 18 p., 1 plate, scale 1:250,000.

Wisehart, R.M., 1971, Paleoenvironmental analysis of the Bear Lake Formation (upper and middle Miocene), Alaska Peninsula, Alaska: Los Angeles, CA, University of California, M.S. thesis, 112 p.

Worrall, D.M., 1991, Tectonic history of the Bering Sea and the evolution of Tertiary strike-slip basins of the Bering Shelf: Geological Society of America Special Paper 257, 120 p., 1 oversize sheet, 4 plates, scale $1: 2,500,000$. 